\title{
TO CORDON OR NOT TO CORDON: THE INHERENT COMPLEXITIES OF POST-EARTHQUAKE CORDONING LEARNED FROM CHRISTCHURCH AND WELLINGTON EXPERIENCES
}

\author{
Shakti R. Shrestha ${ }^{1}$, Caroline H.R. Orchiston ${ }^{2}$, \\ Kenneth J. Elwood ${ }^{3}$, David M. Johnston ${ }^{4}$ and Julia S. Becker ${ }^{5}$
}

(Submitted March 2020; Reviewed April 2020; Accepted July 2020)

\begin{abstract}
The use of post-earthquake cordons as a tool to support emergency managers after an event has been documented around the world. However, there is limited research that attempts to understand the inherent complexities of cordoning once applied, particularly the longer-term impacts and consequences. This research aims to fill the gap by providing a detailed understanding of cordons, their management, and the implications of cordoning in a post-earthquake environment. We use a qualitative method to understand cordons through case studies of two cities where cordons were used at different temporal and spatial scales: Christchurch (M6.3, February 2011) and Wellington (M7.8 in Kaikōura, November 2016), New Zealand. Data was collected through 21 key informant interviews obtained through purposive and snowball sampling of participants who were directly or indirectly involved in a decision-making role and/or had influence in relation to the cordoning process. The participants were from varying backgrounds and roles i.e. emergency managers, council members, business representatives, insurance representatives, police, and communication managers. We find that cordons are used primarily as a tool to control access for the purpose of life safety and security, but cordons can also be adapted to support recovery. Broadly, our analysis suggests two key aspects, 'decision-making' and 'operations and management', which overlap and interact as part of a complex system. The underlying complexity arises in large part due to the multitude of sectors affected by cordons: economics, law, politics, governance, evacuation, civil liberties, available resources etc. The complexity further increases as the duration of cordoning is extended.
\end{abstract}

\section{INTRODUCTION}

The global impact of seismic events has been devastating and the risks due to earthquakes are increasing as more people move into urban environments. In the last two decades alone (19982017), earthquakes have caused 747,000 fatalities [the highest among all the natural hazards] and an economic loss of US \$661 billion around the world [1]. Earthquakes are an inevitable force of nature. They are complex geo-physical events with inherent uncertainty, such as magnitude, depth, time, frequency, and location of occurrence. This is further complicated by external factors such as the vulnerability and exposure of people, population density, the built environment, the structural competence of buildings, and societal awareness and preparedness. Seismic risk, therefore, poses a 'wicked' problem and a serious challenge in both pre-event planning and post-event response.

Post-earthquake cordons have been used in response to seismic events around the world [2-4]. Cordons, simply put, restrict movement to and from a given area [5], acting as a tool to control access in and out of a damaged zone. Cordons can be used in post-disaster situations where authorities are trying to bring some control to otherwise chaotic circumstances. Consequently, when access is restricted from a given area, normal functions are inhibited for individuals, businesses, communities, and institutions both within the cordon and more broadly as a consequence of the cordon. Thus, there are significant challenges associated with cordons.

\section{UNDERSTANDING CORDONS AND THEIR NEED}

The first challenge in understanding cordons lies in defining the term itself. There is currently a limited understanding of what a cordon is, and this simplistic approach does not reflect the complex and multi-layered implications cordons may have. As such, first we dissect the various elements associated with cordons. The word cordon is a diminutive of 'corde' meaning string, rope or line which is borrowed from the Latin word 'chorda' [6]. It should be noted that the term 'cordon' referred to hereafter is the line or boundary created to restrict movement (see [6] for other meanings). Commonly, a cordon is observed to be a tape around a given site that demarcates a barrier line. However, the demarcation (barrier) could also be achieved through traffic cones, metal fences, personnel and an area's natural features [5] depending on available resources, site features and the sensitivity of the situation.

Cordons are established by an authorized body during emergencies and critical situations where there is a need to restrict the access of the general public to a specific area to avoid its exposure, i.e., when there is a clear risk to life safety or a high degree of criticality to a situation. For example, it is commonly used by the police to secure crime scenes. Defence forces often use cordons in various strategic ways during military operations such as investigating suspected terrorist activities [7] and firefighters use cordons as an effective means for safeguarding people and controlling resources [8]. Health organizations can also establish a cordon if there is potential bio-hazard risk.

\footnotetext{
${ }^{1}$ Corresponding author, PhD Candidate., University of Otago, Dunedin, shakti.raj.shrestha@ postgrad.otago.ac.nz

${ }^{2}$ Dr, University of Otago, Dunedin, caroline.orchiston@otago.ac.nz

${ }^{3}$ Professor, The University of Auckland, Auckland (Member)

${ }^{4}$ Professor, Massey University, Wellington (Fellow)

${ }^{5} \mathrm{Dr}$, Massey University, Wellington (Member)
} 
The cordon demarcation makes a clear distinction between people with authorized access within or around the cordon boundary and people without access. The lead emergency response agency (e.g. police, fire, Emergency Management) establishes a cordon and controls the movement of people in and out of it. This controlled movement can be further streamlined through establishing two cordons: an inner cordon and outer cordon. An inner cordon is established around the incident area only and is meant for emergency responders only [5]. Everyone else within the cordon is evacuated. Outer cordons cover a larger area and thus enable authorities to control a wider area which may be necessary to manage broader traffic movement [5]. It also allows emergency personnel to work uninterrupted by the public, with a degree of privacy [8].

Authorities define the spatial extent of the cordon as they deem necessary, and the duration of its placement. The cordon is usually maintained for a short period of time as most emergencies and critical situations themselves are short lived, ranging from a few hours to few days (rarely for weeks or more). Thus, cordons can be generally considered as temporary arrangements. This temporality suggests that the direct impacts of the cordon itself are relatively short term and the inconvenience it may cause to day-to-day lives is limited.

It is reasonable to assume that cordon establishment is generally appreciated by the public given the sensitive nature of the circumstances and/or risk to life safety, buttressed by the understanding that the cordon will be in place for a short period of time. However, cordons can be in place for a longer period even if the degree of criticality is reduced. For example, in some cases a cordon remains to prevent unauthorized entry to the scene such that the integrity of the scene is maintained for potential investigation and/or complete final assessment of the situation. In situations requiring extensive demolition and reconstruction, a cordon supports responsible personnel to work swiftly and efficiently without concerns for traffic management and public safety. But the barriers that demarcate its boundary are often flimsy (i.e. tape, light barriers etc.) and could easily be permeated by the general public. As such, a cordon is often supplemented by authorized personnel (police/army) at various access points and there is an expectation that the public will respect the barrier and not seek access without permission.

\section{Post-Earthquake Cordons}

A cordon established after a seismic event can be described as a post-earthquake cordon. The risk to life after seismic events comes from unstable built structures, falling debris and aftershocks, which poses sufficient risk to life to warrant restricted access. Additionally, risks maybe induced from secondary effects caused by earthquake such as landslides, fires, gas leaks etc. Many of the issues surrounding post-quake cordons are similar to other emergencies, however, there are some peculiarities that are specific to earthquakes. First, documented use and impacts of cordons after a seismic event are rare, and there is a lack of operational knowledge or a guiding framework to understand who can establish a cordon, when, for how long and to what extent. Second, a major earthquake is followed by numerous aftershocks which can continue for many months, which can exacerbate the damage caused by the mainshock. As a consequence, risk to life safety is potentially extended and thus the need for cordons over a prolonged period may become necessary.

Medium to long term cordoning has multiple implications for evacuated people who require temporary housing and businesses that are forced to relocate. Day to day life well beyond the cordon can be disrupted due to schools and banks remaining closed and as people lose their livelihoods. The social fabric of communities can be drastically altered by the closure of places where people meet and socialize, for example cafes, restaurants, and public recreation facilities. This was observed after 2009 L'Aquila, Italy earthquake where the cordoning of the historic city centre for an extended period of time [9] displaced the social activities away from the once vibrant Piazza [10]. These challenges were also laid bare after the February $22^{\text {nd }}$ Christchurch earthquake where cordons had implications across various dimensions of response and recovery [11-14]. Perhaps partly as a consequence of the events in Christchurch, long term cordoning after earthquakes is controversial $[4,15]$. However, post-quake cordoning is an unfortunate reality in many cases [3]. This research proposes there is a need to improve the management and operational aspects of urban post-earthquake cordons in order to expedite response and recovery efforts in disaster zones, using an approach that accounts for the complex, long term impacts of restricted access for the wider community following an earthquake disaster.

\section{METHODOLOGY}

This study uses a qualitative case study approach to investigate post-earthquake cordons and their establishment following the experience of two New Zealand cities; Christchurch (M6.3 February 2011) and Wellington after the M7.8 Kaikōura earthquake in 2016. The established cordons varied in spatial and temporal scales which allowed for a detailed investigation of what cordons constitute and the underlying principles of their establishment and management.

\section{Christchurch}

The city of Christchurch (population 367,700 in 2011) experienced a series of damaging seismic events between September 2010 and December 2011. Among these events, the February $22 \mathrm{nd}$ earthquake $(12.56 \mathrm{pm})$ was the most significant, causing 185 deaths, partial or complete damage to thousands of houses and approximately $\$ 40$ billion in economic damage [13]. A national state of emergency was declared, which was in place until the end of April 2011. The impacts of the earthquake were felt across many sectors [16-18]. The major damage to the central business district (CBD) resulted in the unprecedented situation of a CBD cordon being in place for more than two years. 114 blocks were cordoned off immediately after the earthquake by the police, which was reduced to 75 blocks after ten days [18]. The cordon was setup under the control of the Ministry of Civil Defence and Emergency Management's National Controller and the responsibility was later transferred to Canterbury Earthquake Recovery Authority (CERA) [3]. The scale of cordon establishment was unprecedented globally [3] and its establishment was considered one of the most important decisions of the response due to its direct impact on recovery [19]. The CBD cordon reduced in size over time, illustrated in Figure 1 . The cordon management was a significant challenge and affected many aspects of response and recovery directly. For example, the main operation center of Orion New Zealand Ltd., the electricity distribution company in the city, was within the cordon. Regular access within the cordon was necessary for Orion staff but inconsistent and inflexible arrangements of access hindered their work [20]. Similarly, telecommunication infrastructures were also within the cordon and relevant staff required access 24/7. However, this became a major issue due to ineffective cordon operations [20]. 

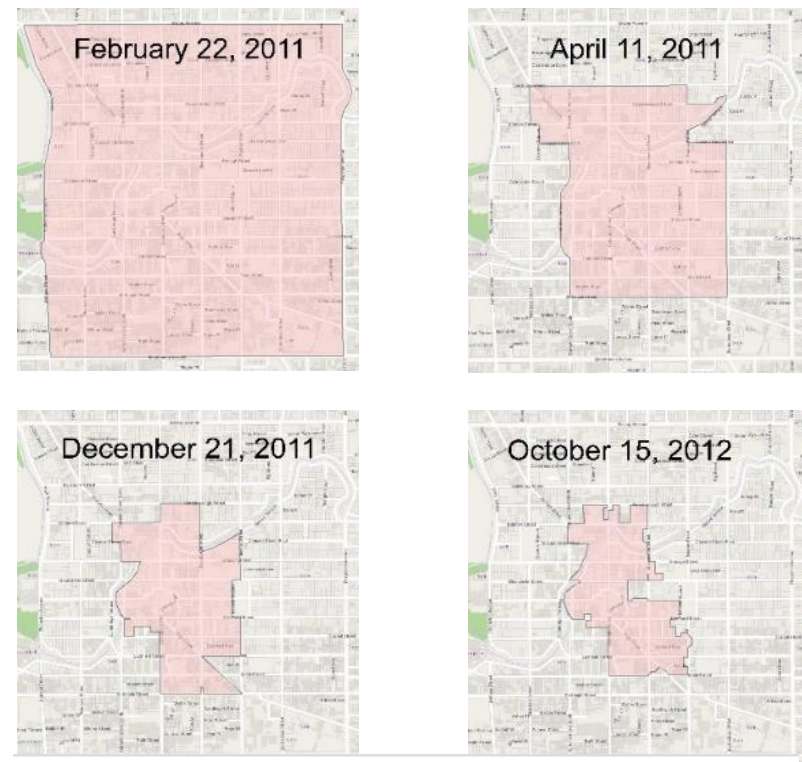

Figure 1: Different phases of cordon reduction for Christchurch CBD [among 22 changes]. Source: Reprinted from Hatton et al. (2012, p.29-30).

\section{Wellington}

Wellington is the capital city of New Zealand (population 207, 900 in 2011) and is highly susceptible to earthquake risks. On November 14th 2016 (12.02am), the city was disrupted by the Kaikōura earthquake ( $\mathrm{Mw} 7.8$ ) which ruptured a number of faults [21]. Wellington lies more than $200 \mathrm{~km}$ away from the epicentre of the quake [22] but it caused damaged to multiple buildings as well as minor disruption to lifeline services [23,24]. A state of emergency was not declared by local authorities in Wellington and the decision was taken not to establish a cordon around the entire city centre. However, there were two main cordons established; firstly, around 61 Molesworth Street (Figure 2), and secondly in Tory Street, both of which were in place for 3-4 months. There were additional minor cordons around Featherston Street.

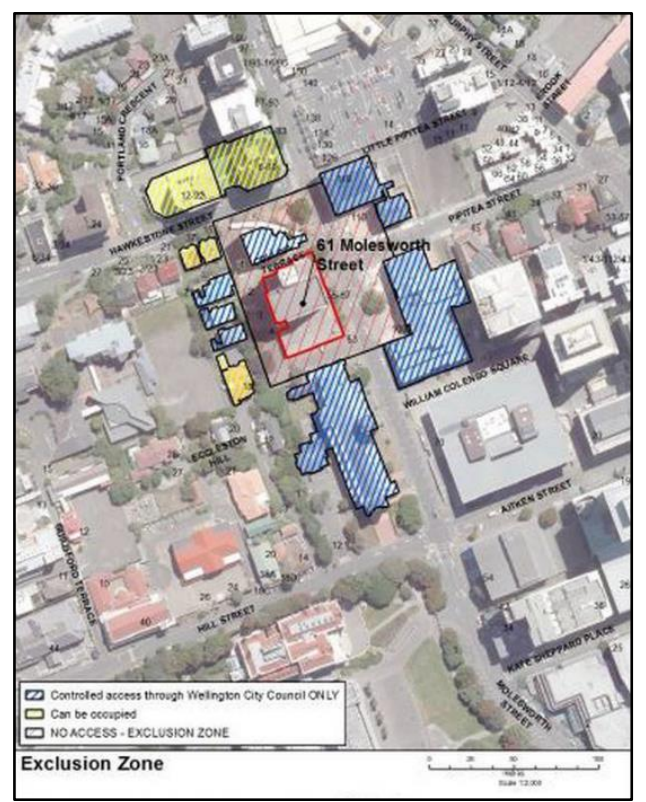

Figure 2: Cordon around 61 Molesworth street, Wellington. Source: https://www.rnz.co.nz/news/national/318239/quakehit-wgtn-building-could-collapse-in-an-aftershock.

\section{Data Collection and Analysis}

Qualitative data for this study was collected through 21 expert interviews obtained through purposive and snowball sampling techniques. Key informants were directly or indirectly involved in a decision-making role and/or management of the cordons or had influence in relation to the cordoning process. The participants were from varying backgrounds and roles i.e. emergency managers, council members, business representatives, insurance representatives, demolition consultants, communication managers and the police. The number of interviews focused on Christchurch $(n=13)$ is higher than in Wellington $(n=8)$ due to the scale and duration of cordon placement. As such, there was more information available of actual experiences and associated impacts for Christchurch. However, many of the interviewees had been involved in both processes and thus had knowledge of both contexts and were able to compare and contrast their experiences of the cordons in Wellington and Christchurch. The difference in scale and duration of cordon placement in these two case studies allowed for a holistic understanding of cordon attributes, operational requirements, and associated decisions as well as its impact on recovery. The questions were semi structured and focused on varying topics depending upon the expertise and roles of the interviewee. In general, the questions were categorized into, short, medium, and long-term impacts of cordons where applicable (based on knowledge and duration of involvement of informants). Table 1 provides some of the general questions that were asked during the interviews. On average, interviews lasted approximately $45 \mathrm{mins}$, with some shorter $30 \mathrm{mins}$ or longer 90mins. The data was then transcribed, and codes were generated inductively. After the codes were generated, transcripts were re-read and matched with associated codes. Few transcript sections were updated into another pre-existing code. The codes were then grouped based on underlying themes and concepts and analysed inductively.

\section{Table 1: Examples of Questions asked during interviews.}

\begin{tabular}{|c|c|}
\hline $\begin{array}{l}\text { Time } \\
\text { frame }\end{array}$ & General Questions \\
\hline $\begin{array}{l}\text { Short- } \\
\text { term }\end{array}$ & $\begin{array}{l}\text { - Who took the decision to establish initial cordon/s? } \\
\text { - What were the underlying reasons for the decisions? } \\
\text { - What type of information is necessary during initial } \\
\text { cordon establishment? } \\
\text { - What were the major challenges during the initial } \\
\text { period of cordon establishment and management? }\end{array}$ \\
\hline $\begin{array}{l}\text { Mid- } \\
\text { term }\end{array}$ & $\begin{array}{l}\text { - The cordon was reduced gradually [in Christchurch]. } \\
\text { What were the major considerations taken for } \\
\text { reducing cordons? } \\
\text { - How did the extended timeframe of the cordons } \\
\text { impact businesses, transport, and temporary housing? } \\
\text { - Was the extent and management of cordon flexible? } \\
\text { Could it have been more flexible, both in terms of the } \\
\text { spatial extent and access? } \\
\text { - How was the information related to cordons } \\
\text { communicated to the public? Do you think the public } \\
\text { should be involved [if so, when?] in decision making } \\
\text { and cordon implementation? } \\
\text { - What type of information do you need for effective } \\
\text { cordon management during this timeframe? }\end{array}$ \\
\hline $\begin{array}{l}\text { Long } \\
\text { term }\end{array}$ & $\begin{array}{l}\text { - How did the cordons impact recovery of the city? } \\
\text { - What was the effectiveness of the cordon, especially } \\
\text { if you consider the long-term implications? In } \\
\text { hindsight, was having the cordon in place for such a } \\
\text { long period necessary? } \\
\text { - Do you think cordoning should be a part of a disaster } \\
\text { recovery framework? }\end{array}$ \\
\hline
\end{tabular}




\section{RESULTS AND DISCUSSION}

The results and discussions are presented together in the following paragraphs.

\section{Understanding Cordons}

There is a suggestion of scale, duration and criticality associated with the term 'cordon'. In relation to size, post-earthquake cordons typically encompass a wider area than a single house. It is different than a 'barricade' which only blocks off a building or a part of a building [25]. In L'Aquila, Italy after the 2009 earthquake, the entire central business district was cordoned off [2]. Similarly the initial cordon in Santa Cruz after the Loma Prieta earthquake in 1989 covered 9 blocks [4]. The extensive Christchurch cordon demonstrated this suggestion of scale consistently for a long period of time as even when gradually reduced over two years, the cordon still covered many blocks of the city (Figure 1).

"So, a cordon is usually more than just one building. A cordon implies that it goes all the way around, otherwise it's a safety barrier which is sort of one building"

- Emergency Manager, Christchurch

The establishment of a cordon means there is a critical situation that justifies the need to remove the general public from a defined space. For post-quake cordons, the criticality of the situation is due to the potential collapse of buildings and/or falling debris. This criticality is sustained for a longer time after an earthquake because the vulnerability of built structures against collapse may not be visibly apparent until detailed engineering assessments are carried out. Depending on the scale of the disaster, these assessments may be necessary for numerous buildings which would require significant expert human resources that may or may not be available immediately. The longer it takes to carry out the assessments, the longer the criticality of the situation will persist.

\section{"It depends on the level of emergency.... Featherston Street, that largely got cordoned off because of falling glass hazards, there was a lot of glass there"}

- City Council representative, Wellington.

Also, major earthquakes are followed by frequent aftershocks that could further reduce the structural integrity of built structures or dislodge debris which could fall on people. While experts understand these risks, the public is often unaware and thus may demand access within the cordon and/or removal of the cordon to access their properties and retrieve their belongings or pets. This demand is also shared by businesses, insurance companies and politicians, among others, when cordons are placed for prolonged periods of time.

“' That building is standing, that must be okay', and I will be saying to them, no, it is sitting on broken foundations on liquefiable land with massively damaged infrastructure underneath it. Just because it is standing does not mean that it's safe. I had that conversation probably 500 times"

\section{- Emergency Manager, Christchurch}

"In the end I think, every aftershock was a bonus to us in some regards because it helped reinforce why the cordon existed"

- Emergency Manager, Christchurch

While the primary purpose is life safety, cordons also serves additional purposes. By creating a restricted zone, it forms a secure area which may be necessary to protect against theft and looting. International experiences have shown that looting may occur after major disasters $[26,27]$ but is often less an issue than many emergency management or law-enforcement agency plan for. Christchurch too had cases of looting after both the September 2010 and February 2011 earthquakes [28].

"I think it was as much about controlling the security of the city as it was about keeping people safe and out of the central city because the opportunity for a degree of disorder was very high. There were people coming in and looting"

- Demolition Consultant, Christchurch.

Cordons can also be used to support recovery. This is because the space within a cordon allows for reduced bureaucratic requirements (for example, reduced 'red tape' for demolition/reconstruction) and logistical requirements (for example, traffic management). In Christchurch, this opportunity was used by some businesses to expedite demolition and repair works within the cordons.

Although significant in purpose, the materials used to demarcate the cordon are often flimsy tapes or light weight barriers, which means they can be easily crossed. This was observed in Christchurch, with several interview participants describing the cordon barrier as 'porous'. Similarly, the porosity of cordons was also observed in Wellington.

"There was one instance where there was a paper being delivered in Tory Street (inside the cordons)"

- City Council representative, Wellington

It is unlikely that a member of the public would enter a cordoned off area if they were aware of a direct danger to themselves, e.g. an active shooter, fire or a building at risk of collapse. Thus, the ability of a cordon to restrict the public from unauthorized access is in part dependent on the public's knowledge of the risk within its boundary. However, with time, the public might be willing to take more risks as the potential risk to life safety is surpassed by certainty of loss of livelihoods, or loss of control over their lives.

"On the other hand, cordons are only a suggestion of security, they are not a fixed wall, so they are a permeable barrier to improve safety around damaged buildings"

\section{- Emergency Manager, Christchurch}

Although relatively simple in their function, cordons are a powerful tool for control. Within the cordons, CERA had the ability to legally demolish buildings if they deemed the building to be unsafe, even without the expressed permission of the building owner. Although justified by safety concerns, by taking command of the situation, control was taken away from the public. By controlling the movement of people and allowing access to only select groups of people, the space within the cordon becomes exclusive and unreachable for the general public. In Christchurch many of the residents were unable to witness the true extent of damage in the CBD area. For many people it was difficult to understand why the cordon was setup for such a long time. The ability to witness it yourself was controlled by the authorities for a long time which only fuelled the curiosity to observe what lay within the cordon. The urban myths that circulated of rat infestations and dead bodies in the CBD [12] highlights the mystery that surrounded the cordon in Christchurch.

"So, it's just about you know, people why were people wanting to get in there. Nine times out of ten people just wanted to go in for a look.... I remember this dear old lady; she came to the cordon for three 
months every day. Dear old lady, she was in her $80 s^{\prime \prime}$

\section{- City Council representative, Christchurch}

The identity of the city is interlinked with the identity of its residents $[29,30]$ and when a significant portion of the city is damaged as in Christchurch, the impact is felt beyond the physical, economic and social. The impact is deeply embedded in people's psyche. This perception is exacerbated when people are not allowed to witness the damage to their homes, the streets they often travelled, a popular landmark or a favourite café

\section{"You know the cordon was not just a physical barrier, but it was almost this emotional, spiritual barrier....it almost felt like people were cut off from the heart of their city, from their identity"}

\section{- Communications Manager, Christchurch}

In Wellington, such extremes were avoided mainly because the cordon was much smaller in extent and duration, and thus the broader negative implications did not emerge.

\section{Cordons and Decision-Making}

The decision to cordon or not after an earthquake is simple if there is visible damage to buildings. Decision makers from both case study areas agree that if there is a clear risk to life safety, a cordon should be placed around dangerous structures. Depending on the scale of the disaster, in New Zealand, this decision can be made by the Civil Defence Emergency Management (CDEM), local controller, group controller or national controller. Cordoning falls under broader movement control guidelines which gives the controllers statutory authority to cordon when a state of emergency is declared [5] Additionally, Police can establish a cordon as observed after the February earthquake in Christchurch where the initial cordon was setup by the police. When there is no declaration of state of emergency, the decision associated with cordon establishment rests on the respective Chief Executives of the Local Territorial Authority. This was observed following the Kaikōura earthquake in Wellington and the decisions that were enacted by the council member on behalf of the chief executive.

\begin{abstract}
"As local authority, we took the decision, we took it from a specific area within our Local Government Act that empowers the chief executive. So ultimately it was the Chief Executive that signed a document and I was enacting it on his behalf."
\end{abstract}

\section{- City Council representative, Wellington}

In both case studies, external pressure was applied to influence decisions with varying degree of intensity and success. For example, in Christchurch, owing to the scale and impact, the political pressure applied to reduce the cordon extent and/or allow access within it from different affected groups was significant. At one point, around 100 business owners protested regarding access within the cordon and communication concerns, with some even breaching the cordon [31].

"It was very political. It played heavily into it. It goes back to the part where we talk about the decisionmaking process. All those political activations sitting underneath, what looked like a well-managed cordon, all that political activeness came through"

- Business representative, Christchurch

"In fact, the whole way through, it was a politically charged environment, delicate, lots of highly invested stake holders and multitudes of different opinions"

- Emergency Manager, Christchurch
In Wellington, a more nuanced pressure was applied to open one of the cordons with eventual success.

"It (pressure from businesses) did influence decisionmaking to the extent that, we were wanting to use this as an opportunity to reassess whether Tory Street needed to be an open two-way street. In effect, pressure was brought to bear to our politicians. Well, originally they were resolute and said, 'yes, it is a good idea to keep it close' but the pressure was brought to bear, and they folded"

- Council representative, Wellington

A decision to restrict access to the entire CBD also requires a significant justification. In case of Christchurch, the decision was clearly justified by the risk to life safety due to the extensive visible damage throughout the CBD. Although a decision was made not to cordon off the CBD in Wellington, residents were asked to avoid the city centre initially and to enter the city only after consultations with their employers, creating a non-physical cordon of sorts (essentially allowing the citizens a degree of control for their own safety). Multiple factors contributed to this decision. There was limited visible damage to the buildings, so the risk to life safety was not evident immediately. Other necessary information such as the intensity of earthquake, observed damage levels, number of vulnerable buildings and their location etc. were also not available immediately after the earthquake. This was furthered by economic concerns as well as lack of available resources to cordon off the CBD.

"Because if we do have to red zone even a small part of our economy, then $50 \%$ of our economic activity happens around $3 \mathrm{sq} . \mathrm{km}$."

- Council representative, Wellington

The decision to cordon when life safety is not at risk has implications for civil liberties, because of the requirement to evacuate everyone from within the cordon. Mandatory evacuation may create legal challenges as requiring it without proper explanation of its necessity may lead to action in tort [32]. This means, there could be a legal liability for the person/party committing the tortious act towards the claimant due to loss or harm caused to the claimant.

"You know, it is imposition on democracy and everything else to actually close up sections of the city. So, you want to be absolutely sure"

\section{- Emergency Manager, Wellington}

Cordoning decisions are challenging, and unique to each case. In the case of Christchurch, the extended duration meant that there were changes in governance structure and personnel, involvement of more stakeholders and increased bureaucracy over the years. This affected decision making as it took more time to take decisions than during the immediate response and early recovery phase (2-3 months).

\section{"It was easier earlier on when the risk was absolutely apparent and there was a small number of people involved around decision making who understood the problem. Overtime that changed", \\ - Emergency Manager, Christchurch \\ "Cordon decisions are easy during response; it is difficult during recovery"}

\section{- City Council representative, Wellington}

Another challenge for decision makers is that they may not have credible, complete, and useful information at the right time to inform their decision. As a consequence, innovative techniques 
were used in both cities to collect the necessary information. In Christchurch, for example, indicator buildings were established that measured the effect of aftershocks on the structural integrity of key buildings, which could then be a used as a proxy for wider building damage $[3,20]$. In Wellington, 3D GIS techniques were applied by technical experts to provide useful information to decision makers that put cordons and their impacts into perspective.

One participant described the use of GIS to improve decisionmaking in Wellington:

\begin{abstract}
"...but starting to actually show the spatial information around the cordons and the buildings affected through $3 D$.....it showed how we could actually take that situational information and turn it into actionable intelligence....yeah, this cordon exists, because on the map it just looks like a shadow of the square building but when you go down with the $3 D$ you see it's a big towering building right above you so you start to see how it affects the real world"
\end{abstract}

- City Council representative, Wellington

\section{Cordons and Operations \& Management}

Even when the decision to establish a cordon is straightforward, the spatial extent must be determined by additional factors. The rule of thumb for determining the cordon extent initially is taken as 1.5 times the height of the building when soft barriers are used [33], which is roughly based on potential fall zones of debris as well as protection for emergency workers (given by the distance of reach of cranes while keeping the operator safe during demolitions). In Christchurch, the initial cordon that encompassed the four main avenues was implemented, in part, because it was practical to do so in terms of planning and available resources.

"You would have needed twice as much fencing if we were to put fencing around the building as oppose to one big fence and the logistics around the traffic management and everything"

- Emergency Manager, Christchurch

Once established, two main concerns arise. First, what are the considerations for reducing the spatial extent of the cordon, and second, how is access managed. Reducing the size of cordons is directly dependent on the demolition of unsafe structures within it [5]. This was evident in both case study sites. In Wellington, when a tall building was being demolished, simultaneously, the cordons were reduced to allow for movement of people as soon as it was safe to do so, which was welcomed by the public.

"There's a Sunday market that takes place at the courtyard of this church and you know as soon as we could......push it up [reduce the cordon], even small bits you know and allow people to park their cars there. You know just every little bit people appreciate"

\section{- City Council representative, Wellington}

Shipping containers can be used to facilitate movement under risky buildings for safe passage of the public that will allow the authorities to significantly reduce the cordon extent. The use of such containers can be seen around construction sites and were also used in Wellington after the earthquake. However, it should be noted that, although shipping containers offer a practical solution to avoid disruptions to movement of people, the containers may not be able to withstand the weight of heavy debris fall, for example, an entire masonry wall.
In Christchurch, the scale of the disaster was such that building demolitions took place over a prolonged period of time, which limited the ability to reduce the cordon quickly. The cordon reduction was also influenced by economic considerations as it was cheaper to work within the cordons.

"And the cost of demolishing tall buildings in a live city is twice as much it is inside the cordon. So, it was more cost effective to keep the city shut. Given that, even if they reopened the city, there was going to be no shops open, there was very little to do"

\section{- Emergency Manager, Christchurch}

The cordon reduction was partly prioritized based on societal and commercial needs, as efforts were made to get a major grocery store out of the cordon [3]. In one section of Christchurch city, the cordon was reduced such that it facilitated opening of the Re:Start mall, a temporary shopping centre to help the businesses recover by bringing people back into the city centre.

"There were lots of considerations. We would talk to
a number of stakeholders: fire, police, construction
engineers, business owners, tenants, traffic
engineers, NGOs occasionally, depending upon what
the activities were in the area and the list goes on"

\section{- Emergency Manager, Christchurch}

The extended duration of the cordon meant that the public began to demand access to gather their belongings and necessary documents. The access was also important for businesses as some of the contents within the building were vital for the survival of the business [20]. This presented serious challenges as it required an access system to be implemented. While providing access, the public would be accompanied by emergency personnel and an engineer [34] which required significant human and other resources. The time required would vary depending on the potential risks as well as time required to complete the purpose of the visit by the public. The access system was initially fraught with irregularities and confusion as access was determined by the stationed individual at the access point [20]. The access system was improved and at a reasonable speed with photo id system available within a few months. The cordon pass office then managed all of the entry requests [35]. Even this system had issues as identification documents of many people were stuck inside the cordons. A system in place for access management that allows for nuanced consideration is potentially a valuable undertaking which may have significant benefits for future. Such considerations for access were also observed in Christchurch. For example,

"There was this family whose son was in a wheelchair and they had the whole family connection with the building, and they wanted to be there when the building was knocked over. So, we made arrangements for them to come in and escort their son in a wheelchair. We went out of our way to make that stuff happen in a safe manner when it was sensible to do so. So, it wasn't all about being utterly efficient and saving costs, we were given a better mandate to be respectful to people"

\section{City Council representative, Christchurch}

The operational challenges are significant when managing such a large cordon due to required dedicated resources, interactions between multiple stakeholders and lack of pre-planning. The lack of pre-planning was considered one of the most significant issues in cordon management [20]. The challenges are further complicated by external pressures that may arise from the public or from political avenues. 
"To be honest, the challenging aspect was dealing with the politicians and people grandstanding with their views and making crazy promises to people that they could not keep and then expecting the cordon management to keep up with it"

\section{- Emergency Manager, Christchurch}

The communication and governance challenges were immense as there were multiple stakeholders from within the official structure and outside of it. This meant that both vertical hierarchies as well as horizontal structures of governance needed to be managed with effective communication. In Christchurch, maps were created to show the cordoned areas, the access points and where it was being reduced.

"So, we developed a booklet and that would have a map of the cordon. It would show where the access points were. It would have the different placarding systems, FAQs, you know. Then that was valid as of date to date. Then when we were starting to reduce the cordons, we would produce another booklet that will have the new access points"

\section{- Communication Manager, Christchurch}

But this information was not well communicated to the public and other stakeholders which created confusion and increased frustration among the people. In Wellington, the communication challenge was limited and more localized. For example, in some instances it was difficult to contact people residing in the buildings within the cordoned area as there was no or limited information about the occupants of the building. The inability to communicate with all the stakeholders promptly meant the cordon could not be reduced as quickly.

Cordon decisions and operations interact in a complex system where one informs the other along a dynamic pathway y. The decision to establish a cordon should primarily be based on risk to life safety. When risks to life safety are not apparent, it is important to understand the consequences of establishing a cordon or deciding not to have one. This consideration should also take into account the operation and management aspect of the cordon as even if there is a desire to establish a cordon, it may not be feasible in terms of available human and physical resources. A cordon which does not have the necessary fencing and/or personnel at the entry points may become significantly porous which defeats the purpose of having one. Pre-planning for cordons could ensure that the decision is focused more on potential risk than available resources. Pre-planning would also mean that the relevant authorities will be well informed to take decisions and manage the cordons effectively and efficiently when established. A cordon may be instrumental in saving many lives, hence developing a solid understanding of cordons and their management prior to a disruptive event may expedite recovery of the city and its public.

\section{CONCLUSIONS}

This paper provides an introduction to cordons and their use in post-earthquake conditions through a case study of two cities in New Zealand where cordons were established after seismic events. Cordons are a tool that allow authorities to control access in and out of a defined area. Their establishment is always a means to control or protect against a disruptive circumstance. By virtue of these attributes, cordons are a powerful tool to restrict people's exposure to life safety risks including unsafe built structures and falling debris after earthquakes. Controlling access also provides security against theft and looting. The role of cordons in the recovery phase is important as they create a transition space which could be used to expedite demolition/repair of damaged buildings. Broadly, post-earthquake cordons can be synthesized and viewed along two key aspects, 'decision-making' and 'operations and management'. These key aspects overlap and interact as part of an intricate system driven by governance and communication structures, and processes. The governance and communications encompass vertical hierarchies and horizontal structures which are not limited to the primary organizations that are responsible for decision making and management of the cordon. For example, effective communications should be carried out with businesses, insurance companies, service operators, communities etc. which will support smoother cordon operations and management. It is also likely that good communication with these parties would increase their level of acceptance for cordon establishment over an extended period of time. Cordon operations and management transcend multitude of sectors such as politics, economics, law, evacuation, civil liberties, available resources etc. and as such is a complex operational environment. The complexity is dependent on its scale and further increases as the duration of cordon is extended. Cordons can thus become divisive and controversial if maintained for a long time. As such, cordons should be avoided, if possible, through long term disaster risk reduction and resilience-building measures in high risk urban environments. When established, cordons should be reduced as soon as practicable which could be made easier if there is preplanning for potential cordons for future events.

\section{ETHICS STATEMENT}

The interview programme was approved by the University of Otago Human Ethics Committee under category 'B'. The results of the interviews presented here are anonymized for privacy.

\section{ACKNOWLEDGEMENTS}

The research was funded by QuakeCoRE, the New Zealand Centre of Research Excellence for Earthquake Resilience (Publication number 0483).

\section{REFERENCES}

1 Pascaline W and Rowena H (2018). "Economic Losses, Poverty and Disaster 1998-2017”. Report for the United Nations Office for Disaster Risk Reduction, Geneva, and Center for Research on the Epidemiology of Disasters, Brussels, $33 \mathrm{pp}$. https://doi.org/10.13140/RG.2.2.35610.08643

2 Contreras D, Forino G and Blaschke T (2018). "Measuring the progress of a recovery process after an earthquake: The case of L'aquila, Italy". International Journal of Disaster Risk Reduction, 28: 450-464. https://doi.org/10.1016/j.ijdrr.2017.09.048

3 Chang SE, Taylor JE, Elwood KJ, Seville E, Brunsdon D and Gartner M (2014). "Urban disaster recovery in Christchurch: The central business district cordon and other critical decisions". Earthquake Spectra, 30(1): 513-532. https://doi.org/10.1193/022413EQS050M

4 Schwab Ji, Topping KC, Eadie CC, Deyle RE and Smith RA (1998). "Planning for Post-Disaster Recovery and Reconstruction". 483/484, APA, Washington, 352 pp. https://nehrpsearch.nist.gov/static/files/FEMA/PB2003104 $\underline{335 . p d f}$

5 MCDEM (2015). "Emergency Movement Control". Ministry of Civil Defence and Emergency Management, Wellington, $50 \mathrm{pp}$. https://www.civildefence.govt.nz/assets/Uploads/logisticsdgl/DGL-18-15-Emergency-Movement-Control-PDF.pdf

6 Oxford (2010). "Oxford Dictionary of English" Third Edition. Editor: Stevenson A, Oxford University Press, 2069 pp. https://www.lexico.com/definition/cordon 
7 MCCLL (2005). "Cordon and Search Tactics, Techniques and Procedure". Marine Corps Center for Lessons Learned, Virginia, $14 \mathrm{pp}$.

https://info.publicintelligence.net/MCCLL-

CordonSearch.pdf

8 IFE (2019). "Control Measure - Establish Appropriate Cordon". Institution of Fire Engineers, Leicester, $110 \mathrm{pp}$. https://www.ife.org.za/wp-content/uploads/2020/01/350The-Foundation-for-Incident-Command-109-pages.pdf

9 Alexander D (2013). "An evaluation of medium-term recovery processes after the 6 April 2009 earthquake in L'Aquila, Central Italy". Environmental Hazards, 12(1): 60-73. https://doi.org/10.1080/17477891.2012.689250

10 Contreras D, Blaschke T, Kienberger S and Zeil P (2013). "Spatial connectivity as a recovery process indicator: The L'aquila earthquake". Technological Forecasting and Social Change, 80(9): 1782-803. https://doi.org/10.1016/j.techfore.2012.12.001

11 ICNZ (2018). "ICNZ Submission on the Building Amendment Bill". Insurance Council of New Zealand, Wellington, $12 \mathrm{pp}$.

https://www.icnz.org.nz/fileadmin/Assets/Submissions/IC NZ_submission_on_Building_Amendment_Bill_251018.pdf

12 Mcbride SK (2017). "The Canterbury Tales: An Insider's Lessons and Reflections from the Canterbury Earthquake Sequence to Inform Better Communication Models". $\mathrm{PhD}$ Dissertation, Massey University, Wellington, New Zealand, 464 pp.

https://mro.massey.ac.nz/handle/10179/11847

13 Potter SH, Becker JS, Johnston DM and Rossiter KP (2015). "An overview of the impacts of the 2010-2011 Canterbury earthquakes". International Journal of Disaster Risk Reduction, 14(1): 6-14. https://doi.org/10.1016/j.ijdrr.2015.01.014

14 Hegarty P (2011). "Canterbury Earthquake - Police Response". Christchurch, 69 pp.

15 Dally J. Quake expert praises CBD cordon. The Press, 3 September 2012. http://www.stuff.co.nz/thepress/news/christchurch-earthquake2011/7601420/Quake-expert-praises-CBD-cordon (Accessed 21/06/2019).

16 Platt S (2012). "Reconstruction in New Zealand Post 201011 Christchurch Earthquakes". Cambridge Archiectural Research Ltd., Cambridge, 72 pp.

https://www.carltd.com/sites/carwebsite/files/Reconstructi on $\% 20$ New\%20Zealand\%20Post $\% 202010$ $11 \% 20$ Christchurch\%20Earthquakes 0.pdf

17 Galloway BD and Hare HJ (2012). "A review of postearthquake building control policies with respect to the recovery of the christchurch CBD". Bulletin of the New Zealand Society for Earthquake Engineering, 45(3): 105116. https://doi.org/10.5459/bnzsee.45.3.105-116

18 Comerio M, Elwood K, Mayes R, Berkowitz R, Bruneau M, Dismuke J, Gavin H, Jaiswal K, Kirsch T, Lai T, Marshall J, Mayes R, Mitrani-Reiser J, Morgan T, Mote T, Peek L, Sritharan S, Sutton J, Turner F, Wein A, Yashinsky M and O'Rourke T (2011). "EERI Special Earthquake Report - Learning from Earthquakes". EERI, Oakland, 16 pp.

https://www.eeri.org/site/images/eeri newsletter/2011 pdf /EERI_NewZealand_EQRpt_web.pdf

19 Taylor JE, Chang SE, Elwood KJ, Seville E and Brunsdon D (2012). "Learning from Christchurch: Technical Decisions and Societal Consequences in Post-Earthquake Recovery". Resilient Organisations, Christchurch, 38 pp. https://www.resorgs.org.nz/wpcontent/uploads/2017/07/critical decisions in the recove ry_of_christchurch.pdf

20 McLean I, Oughton D, Ellis S, Wakelin B and Rubin CB (2012). "Review of the Civil Defence Emergency Management Response to the 22 February Christchurch Earthquake". Ian Mclean Consultancy Services Ltd., Roturua, $243 \mathrm{pp}$.

https://www.civildefence.govt.nz/assets/Uploads/publicati ons/Review-CDEM-Response-22-February-ChristchurchEarthquake.pdf

21 Hamling IJ, Hreinsdóttir S, Clark K, Elliott J, Liang C, Litchfield N, Villamor $\mathrm{P}$, Wallace L, Wright TJ, D'Anastasio E, Bannister S, Burbidge D, Denys P, Gentle P, Howarth J, Mueller C, Palmer N, Pearson C, Power W, Barnes P, Barrell DJA, Van Dissen R, Langridge R, Little T, Nicol A, Pettinga J, Rowland J and Stirling M (2017). "Complex multifault rupture during the $2016 \mathrm{M} \mathrm{w} 7.8$ Kaikōura earthquake, New Zealand". American Association for the Advancement of Science, 356(6334). https://doi.org/10.1126/science.aam7194

22 Fleisher S (2019). "Wellington City's emergency management response to the November 2016 Kaikōura earthquake". Australasian Journal of Disaster and Trauma Studies, 23 (2). http://trauma.massey.ac.nz/issues/20192/AJDTS 232 Fleisher.pdf

23 Giovinazzi S, Austin A, Ruiter R, Foster C, Nayyerloo M, Nair N and Wotherspoon LM (2017). "Resilience and fragility of the telecommunication network to seismic events: evidence after the Kaikōura [New Zealand] earthquake sequence". Bulletin of the New Zealand Society for Earthquake Engineering, 50(2): 318-328. https://doi.org/10.5459/bnzsee.50.2.318-328

24 Hughes MW, Nayyerloo M, Bellagamba X, Morris J, Brabhaharan P, Rooney S, Hobbs E, Wooley K and Hutchison S (2017). "Impacts of the 14th November 2016 Kaikōura earthquake on three waters systems in Wellington, Marlborough and Kaikōura, New Zealand: Preliminary observations". Bulletin of the New Zealand Society for Earthquake Engineering, 50(2): 306-317. http://hdl.handle.net/10092/14685

25 MBIE (2019). "Managing Buildings in an Emergency". Ministry of Business Innovation and Employment, Wellington, $136 \mathrm{pp}$.

https://www.building.govt.nz/managingbuildings/managing-buildings-in-an-emergency/

26 Wibawa T. Indonesia tsunami: Palu residents turn to looting as desperation grows. ABC news, 2 October 2018. https://www.abc.net.au/news/2018-10-02/indonesiaearthquake-tsunami-palu-residents-looting-deathtoll/10328882 (Accessed 25/06/2019)

27 Sherwell P and Sawer P. Haiti earthquake: looting and gunfights break out. The Telegraph, 20 January 2010. https://www.telegraph.co.uk/news/worldnews/centralameri caandthecaribbean/haiti/7005554/Haiti-earthquakelooting-and-gun-fights-break-out.html (Accessed 24/06/2019).

28 Gillies A and Leask A. Christchurch earthquake: Looters to have day in court. NZ Herald, 12 September 2010. https://www.nzherald.co.nz/nz/news/article.cfm?c_id=1\& objectid=10672793 (Accessed 25/06/2019).

29 Haapala, A (2003). "The Urban Identity: The City as a Place to Dwell". in Place and Location III. Estonian Academy of Arts, Tallinn, $12 \mathrm{pp}$. http://www.eki.ee/km/place/pdf/kp3_01_Haapala.pdf

30 Lynch K (1960). "The Image of the City". MIT Press, 
Cambridge. 103 pp.

http://www.miguelangelmartinez.net/IMG/pdf/1960 Kevi n_Lynch_The_Image_of_The_City_book.pdf

31 Stuff. Angry cordon jumpers seek talks. the press, 21 March 2011. http://www.stuff.co.nz/the-press/4791575/Angrycordon-jumpers-seek-talks (Accessed 29/06/2019).

32 Kanarev N (1996). "Legal issues associated with evacuation: a theoretical perspective". Australian Journal of Emergency Management, 11(2): 41-6.

https://search.informit.com.au/documentSummary; $\mathrm{dn}=398$ 074205173350;res=IELAPA

33 CALBO (2013). "CALBO's Interim Guidance for Barricading, Cordoning, Emergency Evaluation and Stabilization of Buildings with Substantial Damage in Disasters". California Building Officials, California, 2 pp. https://www.calbo.org/sites/main/files/file- attachments/guidanceforbuildingswithsubstantialdamagein disasterspublishedjuly2015.pdf?1525122335 (Accessed 18/05/2019).

34 Stevenson JR, Kachali H, Whitman Z, Seville E, Vargo J and Wilson T (2011). "Preliminary observations of the impacts the 22 February Christchurch earthquake had on organisations and the economy: A Report from the Field [22 February-22 March 2011]". Bulletin of New Zealand Society for Earthquake Engineering, 44(2): 65. https://www.nzsee.org.nz/db/Bulletin/Archive/44(2)0065. pdf

35 CERA (2016). "Cordon access for property owners, tenants and residents". Canterbury Earthquake Recovery Authority, Christchurch, 3 pp.

https://quakestudies.canterbury.ac.nz/store/object/524726 